\title{
The Effect of Zinc and Magnesium Ions on the Development of Staphylococcal Biofilm
}

\author{
Olha S Voronkova* \\ Department of Modern Technologies of Diagnostic and Treatment Process, Ukraine
}

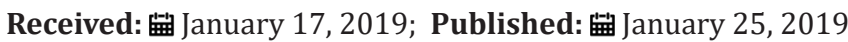

*Corresponding author: Olha S Voronkova, Department of Modern Technologies of Diagnostic and Treatment Process, Dnipro, Ukraine

\section{Short Communication}

In view of the presence of protein components in the staphylococcal biofilms, it may be interesting to study the effect on the biofilm formation of metal ions, since it is known that the activity of certain peptidases and proteases, as well as of a number of enzymes associated with the functioning of the genome, depends on the concentration of some bivalent metal ions. The aim of the research was to study an influence of zinc and magnesium ions on the development of staphylococcal biofilm. The study of the influence on the formation of biofilms by staphylococci of Mg2+ and $\mathrm{Zn2+}$ ions was carried out when these ions were added in the form of nitrate salts to synthetic medium (the final concentrations were from 0.05 to $12.8 \mathrm{mM}$ ). The control sample was the medium without the addition of the specified compounds. Contents of synthetic medium described in [1]. The $\mathrm{pH}$ value of the medium for growing of staphylococci was 7.5-7.6. $200 \mu \mathrm{l}$ of a sterile base medium was added to the wells of a 96-well plate (Medpolimer, RF) with or without addition of ions and $100 \mu \mathrm{l}$ of a bacterial suspension contained $1.0 \times 104$ cells / ml were sowed. Plates incubated for 72 $\mathrm{h}$ at $37^{\circ} \mathrm{C}$.

The development of biofilm was studied by method [2]. The results of studies on the influence of ion of bivalent metals showed that the concentrations of zinc and magnesium cations in the culture medium from $0.05-12.8 \mathrm{mM}$ resulted as a decrease of the number of cells and the biofilm-formation index (BI). That is, there was a suppression of the formation of biofilms. In particular, the use of ions $\mathrm{Mg} 2+$ already in the concentration in the nutrient medium of $0.05 \mathrm{mM}$ led to a decrease in the number of cells of biofilm 10.5 times, while the index of biofilm-formation was reduced by 1.2 times, and at a concentration of $12.8 \mathrm{mM}$ the number of cells decreased by $6.06 \times 106$ times, and BI -14 times compare to the control. During the study of the effects of various concentrations of $\mathrm{Zn2+}$ ions, it was found that the number of cells in a biofilm that was formed in a nutrient medium containing $0.05 \mathrm{mM} \mathrm{Zn2+}$ ions and the values of BI were not significantly different from the control. An increase in the concentration of zinc ions in the culture medium resulted in a gradual decrease in the number of cells in the film, and already at a concentration of $12.8 \mathrm{mM}$ the number of cells decreased by $4.0 \times 105$, and the index of BI -7.0 times compared with the control.

According to the results of similar studies of other authors [3] an increase in the concentration of $\mathrm{Ca} 2+, \mathrm{Mg} 2+$ and $\mathrm{Mn} 2+$ ions in the culture medium provokes a decrease in the activity of formation of staphylococcal biofilms. For example, an increase in the medium of cultivation of ions $\mathrm{Mn} 2+$ to $12.5 \mathrm{mM}$ reduced the formation of biofilms by 5 times. The addition of $\mathrm{Ca} 2+$ and $\mathrm{Mg} 2+$ ions into the culture medium reduced the intensity of biofilm formation of Staphylococcus epidermidis strains by an average of 2 and 3 times, respectively. Other authors [4] cite data, indicate that in the presence of iron ions in the culture medium suppress the formation of biofilms by Staphylococcus aureus, and the deficiency of iron ions, by contrast, enhances the formation of the biofilm. Consequently, compared to the natural concentration of the metals ions in the media have a negative effect on the formation of the film, however, and the lack of these ions has negative consequences. In particular, in another studies [5] have shown that a staphylococcal biofilm is not formed if the $\mathrm{Zn2+}$ ions are absent in the culture medium, because they are elements of intercellular interactions at the level of the surface proteins of bacterial cells.

\section{References}

1. Evglevsky DA, Evglevsky AA, Semenyutin VV, Smirnov II, Tatarnikov KV (2011) Universal synthetic medium for the cultivation of pathogenic and probiotic microorganisms in the preparation of biological products. Vestnik Kurskoy gosudarstvennoy sel'skokhozyaystvennoy akademii 4: 64-66.

2. Stepanovic S, Vukovic D, Dakic I, Savic B, Svabic-Vlahovic M (2000) A modified microtiter-plate test for quantification of staphylococcal biofilm formation. J Microbiol Met. 40(2): 175-179. 
3. Korobov VP, Lemkia LM, Monkhov VI (2010) Analysis of the sensitivity of the formation of Staphylococcus epidermidis 33 biofilms to some environmental factors. Vestnik Permskogo universiteta. Biologiya 1(1): 59-63.

4. Chen L, Wen YM (2011) The role of bacterial biofilm in persistent infections and control strategies. Int J Oral Sci 3(2): 66-73.

\section{ISSN: 2574-1241}

DOI: $10.26717 / B J S T R .2019 .13 .002428$

olha S Voronkova. Biomed J Sci \& Tech Res

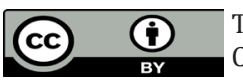

This work is licensed under Creative Commons Attribution 4.0 License

Submission Link: https://biomedres.us/submit-manuscript.php
5. Conrady DG, Wilson JJ, Herr AB (2013) Structural basis for Zn2+dependent intercellular adhesion in staphylococcal biofilms. Proc Natl Acad Sci USA. 110(3): 202-211.

$\begin{array}{ll}\text { BIOMEDICAL } & \text { Assets of Publishing with us } \\ \text { RESEARCHES } & \text { - Global archiving of articles } \\ & \text { - Immediate, unrestricted online access } \\ & \text { - Rigorous Peer Review Process } \\ & \text { - Authors Retain Copyrights }\end{array}$

